\title{
Molecular differentiation of the four most commonly occurring Trichogramma (Hymenoptera: Trichogrammatidae) species in China
}

\author{
ZHENG-XI LI \\ Department of Entomology, China Agricultural University, 2 Yuanmingyuan West Road, Beijing 100094, China; \\ e-mail: zxli@cau.edu.cn
}

\begin{abstract}
Key words. Trichogrammatidae, Trichogramma, molecular identification, species-specific primers, restriction fragment length
\end{abstract} polymorphism, random amplified polymorphic DNA

\begin{abstract}
Trichogramma dendrolimi, T. ostriniae, T. confusum and T. evanescens are the four most commonly occurring Trichogramma species with overlapping distribution in China. They are the most frequently used egg parasitoids for biological control of lepidopterous crop pests in China. It is difficult to differentiate Trichogramma species because of their small size and lack of differences in morphological characters. Different molecular markers were employed to molecularly characterize and differentiate these species, including direct amplification of the internally transcribed spacer 2 (ITS2) of ribosomal DNA by polymerase chain reaction (PCR), restriction fragment length polymorphism (RFLP), random amplified polymorphic DNA (RAPD) and species-specific primers. The results showed that direct amplification of ITS2 could not clearly discriminate these species, but they could be differentiated using RFLP pattern obtained with endonucleases EcoRI and HindIII. The banding pattern produced by RAPD is irreproducible so it is not a suitable way to identify Trichogramma species. Finally, the species-specific primers designed based on ITS2 sequences could unequivocally distinguish the four species. The species-specific primer-based protocol proved to be the most convenient and time saving method for the identification of Trichogramma species by creating a unique PCR product, which can be used in surveying natural populations of Trichogramma species. This is the first report of the prompt identification of the four most commonly occurring Trichogramma species in China.
\end{abstract}

\section{INTRODUCTION}

T. dendrolimi Matsumura, T. ostriniae Pang et Chen, $T$. confusum Viggiani and T. evanescens Westwood are the most commonly occurring Trichogramma species in China. T. ostriniae is numerically dominant in cornfields, while $T$. confusum is the predominant Trichogramma species in cotton fields. T. dendrolimi mainly occurs in forests, whereas $T$. evanscens is often collected in vegetable fields. Their distribution ranges frequently overlap across the country. For example, over $80 \%$ of the samples collected from cornfields are of $T$. ostriniae, but $T$. confusum, T. evanescens, and $T$. dendrolimi can also occur simultaneously in cornfields. Therefore, it is always necessary to identify the samples collected from fields before further studies are undertaken.

The four Trichogramma species are also the most frequently used egg parasitoids in China. They are extensively used in the biological control of over 20 kinds of lepidopterous pests. It is reported that the annual acreage over which Trichogramma are released in China has reached about 660,000 ha (statistics of the Ministry of Agriculture, P.R.China). Use of species that are best adapted to local environment undoubtedly brings great economic benefits. Obviously, screening for the suitable wasps attaches great importance to species identification. However, protocols for rapid and precise identification of local Trichogramma species in China are still lacking. Therefore, the development of feasible methods for Trichogramma identification is important for making full use of these biocontrol agents.
Trichogramma species are very small $(<1 \mathrm{~mm})$ (Nagarkatti \& Nagaraja, 1971) and morphological identification of them is usually time-consuming, sometimes uncertain. For instance, T. confusum has long been considered as the same species as $T$. chilonis (Lin, 1994), but careful reexamination of their taxonomic status based on ITS2 sequence and other biological characteristics revealed that they might be different species (Li et al., 2004). It was estimated that a total of 142 species belonging to the family Trichogrammatidae occur in China, and it is extremely difficult to distinguish many Trichogramma species based on morphology since these parasitoids are very small and lack of clear morphological differences. What is worse, it is almost impossible to identify the immature stages (eggs and larvae) based on morphological traits.

Various methods have been used to identify Trichogramma species, including morphological comparisons (Stouthamer et al., 1996; Pinto et al., 1997), allozymic analyses (Pinto et al., 1992; Pintureau, 1993) and reproductive compatibility tests (Pinto et al., 1991, 2003; Stouthamer et al., 2000). Recent advances in DNA-based techniques provide useful tools for the rapid identification of these minute wasps (Silva et al., 1999; Hoy et al., 2000). Different DNA- and polymerase chain reaction (PCR)-based molecular markers have been developed for diagnostic purpose, including random amplified polymorphic DNA (RAPD) (Landry et al., 1993; Laurent et al., 1998), restriction fragment length polymorphism (RFLP) (Sappal, 1995), satellite DNA (Landais et al., 2000), and 
Inter-Simple Sequence Repeat (ISSR) (de León \& Jones, 2005). Ribosomal DNA (rDNA) is present in all eukaryotic organisms and the internal non-coding transcribed spacer (ITS) region of rDNA has been extensively used in the examination of the taxonomic status of Trichogramma species (Orrego \& Silva 1993; Van Kan et al., 1996; Pinto et al., 2002). Amornsak et al. (1998) designed a pair of unique primers based on the ITS2 sequences of $T$. australicum and its host for specific PCR amplification of $T$. australicum DNA from individual parasitized eggs, but the primers were unable to distinguish DNAs of different Trichogramma species. Thomson et al. (2003) also used the ITS2 region to identify Trichogramma species from southeastern Australia. Stouthamer et al. (1999) used the size and the difference in restriction fragment length polymorphism (RFLP) of rDNA-ITS2 to construct a simple and precise identification key to the sibling species of the Trichogramma deion Pinto \& Oatman / Trichogramma pretiosum Riley complexes. Chang et al. (2001) used RAPD of genomic DNA and species-specific primers that were designed based on rDNA-ITS1 to differentiate two egg parasitic wasps of the Asian corn borer, i.e. T. ostriniae and T. chilonis. In this study, different molecular markers were compared and finally, the most suitable protocol was selected. This is the first report of a prompt identification of the four most commonly occurring Trichogramma species in China.

\section{MATERIAL AND METHODS}

\section{Insects}

T. dendrolimi, T. confusum, T. evanescens and T. ostriniae were collected in corn and cotton fields with their host eggs (Table 1). Lab-reared populations were established as isofemale lines by individual rearing in the eggs of rice moth, Corcyra cephalonica $\left(25-27^{\circ} \mathrm{C}, \mathrm{RH} 75 \%-80 \%\right.$, and $\left.16 \mathrm{~L}: 8 \mathrm{D}\right)$. The populations used in this study and the corresponding vouchers were all maintained in the Department of Entomology, China Agricultural University. T. dendrolimi were selected for intraspecies study because the largest number of collections is available for this species in our laboratory. Individual neonate female wasps from different cultures were directly used for analysis or preserved in $95 \%$ ethanol in sterilized $1.5 \mathrm{ml}$ tubes at $-20^{\circ} \mathrm{C}$. Fresh wasps of the second generation from each line were

TABLE 1. Trichogramma populations used in this study.

\begin{tabular}{ll}
\hline Populations* & Collection site and time \\
\hline T. dendrolimi_JL & Changchun, Jilin, China, 1993 \\
T. confusum_JL & Changchun, Jilin, China, 1999 \\
T. evanescens_YQ & Yanqing, Beijing, China, 1999 \\
T. ostriniae_JL & Changchun, Jilin, China, 1999 \\
T. dendrolimi_YBL & Yabuli, Heilongjiang, China, 1994 \\
T. dendrolimi_RH & Renhe, Jilin, China, 1994 \\
T. dendrolimi_GZ & Guangzhou, Guangdong, China, 1996 \\
T. dendrolimi_YQ & Yanqing, Beijing, China, 1999 \\
T. dendrolimi_TTG & Tutougou, Heilongjiang, China, 1998 \\
T. dendrolimi_XZ & Xuzhou, Jiangsu, China, 1994 \\
\hline
\end{tabular}

* Populations were coded by combining species names with acronyms of collection sites. soaked in acetic acid, and the male genitalia were examined microscopically for species identification using the procedures of Lin (1994).

\section{Extraction of genomic DNA}

Total genomic DNA was extracted from individual wasps. Neonate wasps were directly used for homogenization. If ethanol-preserved samples were used, the samples were firstly transferred onto sterilized filter paper and the ethanol evaporated prior to homogenization. Individuals were homogenized in $20 \mu 1$ lytic buffer ( $10 \mathrm{mM}$ Tris-HCl, $\mathrm{pH} 8.4,50 \mathrm{mM} \mathrm{KCl}, 0.45 \%$ Tween, $20,0.45 \% \mathrm{NP} 40$, and $100 \mu \mathrm{g} / \mathrm{ml}$ proteinase $\mathrm{K})$. The homogenate was incubated at $65^{\circ} \mathrm{C}$ for $30 \mathrm{~min}$ and then boiled for $10 \mathrm{~min}$ to inactivate the proteinase $\mathrm{K}$.

\section{PCR amplification and restriction profiles}

Primers used for PCR amplification were: TrichF 5'TTCTCGCATCGATGAAGAACG-3' (located in $5.8 \mathrm{~S}$ ) and TrichR 5'-TCCTCCGCTTATTGATATGC-3' (located in $28 \mathrm{~S}$ ) (Amornsak et al., 1998). PCR was performed by initially denaturing DNA at $95^{\circ} \mathrm{C}$ for 3 min, followed by 35 cycles of amplification $\left(94^{\circ} \mathrm{C} 1 \mathrm{~min}, 53^{\circ} \mathrm{C} 1 \mathrm{~min}, 72^{\circ} \mathrm{C} 1 \mathrm{~min} 30 \mathrm{~s}\right)$ and extension at $72^{\circ} \mathrm{C}$ for $10 \mathrm{~min}$. The $25 \mu \mathrm{l}$ reactions contain $2 \mu \mathrm{l}$ DNA lysate, $2.5 \mu 1 \mathrm{MgCl}_{2}(25 \mathrm{mM}), 2 \mu 1 \mathrm{dNTPs}$ ( $2.5 \mathrm{mM}$ each), $1 \mu 1$ primer mixture $(25 \mu \mathrm{M}$ each), and $0.4 \mu 1$ Taq DNA polymerase (2.5 U/ $\mu 1$, TianGen, Beijing, China). Three microlitres of PCR product were subjected to electrophoresis on a $1.5 \%(\mathrm{w} / \mathrm{v})$ agarose gel. Three microlitres of PCR product were digested with EcoRI and HindIII (Fermentas, Beijing, China) according to the manufacturer's instructions. DNA digestions were separated by electrophoresis on a $1.7 \%(\mathrm{w} / \mathrm{v})$ agarose gel.

\section{RAPD banding}

Two microlitres of genomic DNA were used for RAPD PCR in $25 \mu \mathrm{l}$ reactions, containing $1 \mu \mathrm{l}$ random primer $(25 \mu \mathrm{M}), 2.5$ $\mu 1 \mathrm{MgCl}_{2}(25 \mathrm{mM}), 2 \mu \mathrm{d} \mathrm{dNTPs}(2.5 \mathrm{mM}$ each), and $0.5 \mu 1 \mathrm{Taq}$ DNA polymerase $(2.5 \mathrm{U} / \mu 1$, TianGen, Beijing, China). Twenty random primers (Operon 10-mer A01-10, C01-10; Operon Technologies Inc., Alameda, CA) were tested. PCR was performed using the following cycling program: $94^{\circ} \mathrm{C}$ for $3 \mathrm{~min}$ followed by 45 cycles of amplification $\left(94^{\circ} \mathrm{C} 30 \mathrm{~s}, 40^{\circ} \mathrm{C} 25 \mathrm{~s}\right.$, $72^{\circ} \mathrm{C} 1 \mathrm{~min} 30 \mathrm{~s}$, and finally $72^{\circ} \mathrm{C} 7 \mathrm{~min}$ ). PCR products were analyzed by electrophoresis on a $1.5 \%(\mathrm{w} / \mathrm{v})$ agarose gel. At least ten individuals of each culture were analyzed.

\section{Species-specific primers}

Species-specific primers were designed based on approximately 200 ITS2 sequences of the genus Trichogramma. These sequences were retrieved and screened from GenBank (June/2006). Primers were selected based on their specificity and general quality. PCR was carried out by initially denaturing DNA at $95^{\circ} \mathrm{C}$ for $3 \mathrm{~min}$, followed by 35 cycles of amplification $\left(94^{\circ} \mathrm{C} 50 \mathrm{~s}, 52^{\circ} \mathrm{C} 30 \mathrm{~s}, 72^{\circ} \mathrm{C} 1 \mathrm{~min} 50 \mathrm{~s}\right.$, and extension at $72^{\circ} \mathrm{C}$ for $10 \mathrm{~min}$ ). The $15 \mu \mathrm{l}$ reactions contain $1.5 \mu \mathrm{l}$ DNA lysate, 0.6 $\mu 1$ primer mixture $\left(25 \mu \mathrm{M}\right.$ each), $1.5 \mu 1 \mathrm{MgCl}_{2}(25 \mathrm{mM}), 1 \mu 1$ dNTPs (2.5 mM each), and $0.25 \mu \mathrm{l}$ Taq DNA polymerase (2.5 $\mathrm{U} / \mu 1$, TianGen, Beijing, China).

\section{RESULTS}

\section{PCR amplification}

ITS2 fragments were successfully PCR amplified from each of the four Trichogramma species (not shown). The PCR amplicons of ITS2 from $T$. dendrolimi and $T$. confusum were nearly of the same size $(\sim 600 \mathrm{bp})$, and those from $T$. ostriniae and $T$. evanescens were similarly sized $(\sim 630$ bp). These results demonstrate that ITS2 itself 


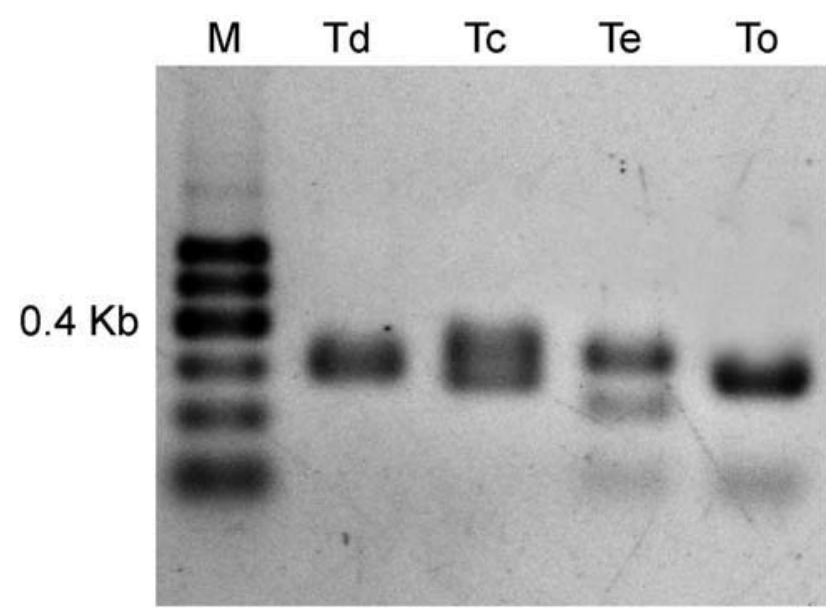

Fig. 1. RFLP profile of the ITS2s of different Trichogramma species using EcoRI and HindIII. Td - T. dendrolimi; Tc $-T$. confusum; Te - T. evanescens; To - T. ostriniae. $\mathrm{M}-$ molecular weight marker (100 bp ladder).

cannot be used to differentiate the four species. Intraspecies analyses using 6 populations from the same species, $T$. dendrolimi, revealed that ITS2 size was consistent within a species (not shown).

\section{RFLP}

RFLP using EcoRI and HindIII produced speciesspecific banding patterns (Fig. 1). ITS2 of T. dendrolimi was cut into two overlapping bands of similar size around $300 \mathrm{bp}$ (only one band visible); ITS2 of $T$. confusum was excised into two visible bands $(300 \pm 40 \mathrm{bp})$. Three visible bands ( 100 bp, $200 \mathrm{bp}$, and $300 \mathrm{bp})$ and two clear bands ( $\sim 300 \mathrm{bp}$ and $100 \mathrm{bp})$ were seen, respectively, in the ITS2 of $T$. evanescens and T. ostriniae. RFLP patterns were reproducible within a species (not shown).

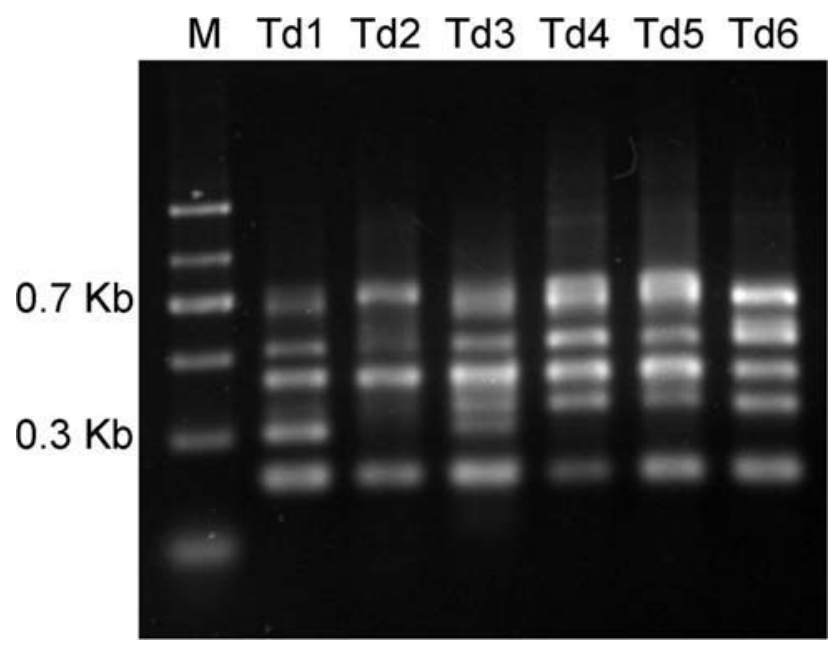

Fig. 2. RAPD banding pattern within a species. Td $1-T$. dendrolimi YBL; $\mathrm{Td} 2-T$. dendrolimi $\mathrm{RH} ; \mathrm{Td} 3-T$. dendrolimi GZ; $\mathrm{Td} 4-T$. dendrolimi $\mathrm{YQ} ; \mathrm{Td} 5-T$. dendrolimi TTG; Td6 - T. dendrolimi XZ. M - molecular weight marker (200 bp ladder).

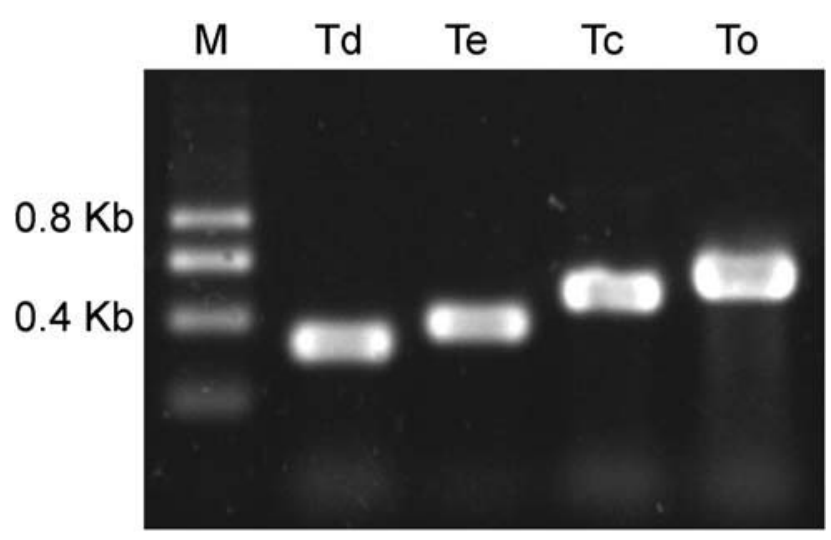

Fig. 3. Identification of Trichogramma species using speciesspecific primers. $\mathrm{Td}-T$. dendrolimi $(340 \mathrm{bp}) ; \mathrm{Te}-T$. evanscens (390 bp); Tc - T. confusum (486 bp); To - T. ostriniae (545 bp). $\mathrm{M}$ - markers (200 bp ladder).

\section{RAPD}

Operon 10-mer C02 (5'-GTGAGGCGTC-3') produced polymorphic bands at species level, but it is not reproducible within a species (Fig. 2). As Fig. 2 shows, 3 major bands $(\sim 700 \mathrm{bp}, 400 \mathrm{bp}$ and $200 \mathrm{bp})$ are reproducible within $T$. dendrolim, but at least one not reproducible band is present, which makes RAPD markers unsuitable for species identification in this case.

\section{Species-specific primer-based identification}

Four pairs of primers were selected for identification of each species. Td340F / TrichR created a PCR product of $340 \mathrm{bp}$ specific for T. dendrolimi DNA; Te390F / TrichR created a PCR product of $390 \mathrm{bp}$ specific for $T$. evanescens; TrichF / Tc486R created a PCR product of $486 \mathrm{bp}$ specific for T. confusum; TrichF / To545R created a PCR product of $545 \mathrm{bp}$ specific for T. ostriniae (Table 2, Fig. 3). This diagnosis protocol is characterized by high species-specificity and detection sensitivity. This method is reproducible within a species as confirmed by six geographical populations of $T$. dendrolimi, which was confirmed by cloning and sequencing (GenBank accession numbers AF453554-AF453561).

\section{DISCUSSION}

Based on the data given in this study, it can be concluded that: (i) these species could not be discriminated only by the size of the amplified ITS2 fragments; (ii) these Trichogramma species could be differentiated using RFLP pattern and species-specific primers, but the latter are the most suitable as they can be used to identify each species quickly and with certainty; (iii) RAPD is not reproducible at intra-species level so it is not suitable for species identification. The species-specific primer-based protocol proved to be the most convenient and time saving method for identification of Trichogramma species and can be used for surveying natural populations of Trichogramma species in the field. This is the first report of rapid identification of the four most commonly occurring Trichogramma species in China. The method might be suitable for identifying other insects. 
TABLE 2. Diagnostic primers used in this study.

\begin{tabular}{llll}
\hline Primer & Sequence $\left(5^{\prime} \rightarrow 3^{\prime}\right)$ & Primer pair & Product $(\mathrm{bp})$ \\
\hline TrichF & TTCTCGCATCGATGAAGAACG & TrichF/TrichR & Variable \\
TrichR & TCCTCCGCTTATTGATATGC & Td340F/TrichR & 340 \\
Td340F & GCAGCAGTCAAGACGACA & Te390F/TrichR & 390 \\
Te390F & CGTAGAGAGAGAGTGCGC & TrichF/Tc486R & 486 \\
Tc486R & GCTGCTGTTGTTGATACAACC & TrichF/To545R & 545 \\
To545R & GCCACTTTGACTCTGATAC & & \\
\hline
\end{tabular}

Morphological identification of Trichogramma species is difficult and when the distribution ranges of different species overlap, several species may be confused during laboratory rearing and sample treatment. This is often the case if a lot of Trichogramma isolines are reared at the same time. Meanwhile, a protocol for rapid identification of Trichogramma species is particularly helpful for classifying specimens collected in a large-scale field survey, since traditional taxonomic methods are both labour intensive and slow, and therefore not suitable for handling large samples. Instead, the molecular method has been used to detect natural field populations (Prinsloo et al., 2002; Ratcliffe et al., 2002; Loxdale \& MacDonald, 2004). Another reason why this method is advisable is that traditional methods require intact and well-preserved specimens, specialized expertise and taxonomic knowledge to fulfill a taxonomic task, but the species-specific primer-based method presented here can be used to identify incomplete specimens and researchers other than Trichogramma experts can identify them.

Detecting early instars and eggs of larval parasitoids, even with the aid of the best light microscopes and appropriate stains, is not an easy task. In contrast, PCR approaches for studying parasitism rates are sensitive and accurate (Greenstone \& Edwards, 1998; Zhu \& Williams, 2002; Erlandson et al., 2003; MacDonald \& Loxdale, 2004). Amornsak et al. (1998) detected the DNA of the parasitoid T. australicum Girault in its host Helicoverpa armigera (Hübner) $12 \mathrm{~h}$ after parasitization. Similarly, Tilmon et al. (2000) found the PCR-based technique to be capable of detecting even a newly laid parasitoid egg within parasitized nymphs of Lygus spp., in which the parasitoid constituted only $0.01 \%$ of the host tissue. Agustí et al. (2005) demonstrated that the percentage of parasitism in Ostrinia nubilalis (Hübner) by Lydella thompsoni (Herting) and Pseudoperichaeta nigrolineata (Walker) given by a traditional method was three times lower than that revealed by the molecular method. Molecular detection and identification of immature stages is especially useful for quality control of Trichogramma species that are commercially reared and released as biocontrol agents. Laboratories that specialize in mass rearing of Trichogramma, where species identification, quality control and population monitoring are very important, usually have PCR thermocyclers that allow the use of this technique.

ACKNOWLEDGEMENTS. This study was supported by National Basic Research Program of China (Grant No. 2006CB102006) and National Science Foundation of China (Grant No. 30571218).

\section{REFERENCES}

Agustí N., Bourguet D., Spataro T., Delos M., Eychenne N., Folcher L. \& ARditi R. 2005: Detection, identification and geographical distribution of European corn borer larval parasitoids using molecular markers. Mol. Ecol. 14: 3267-3274.

Amornsak W., Gordh G. \& Graham G. 1998: Detecting parasitized eggs with polymerase chain reaction and DNA sequence of Trichogramma australicum Girault (Hymenoptera: Trichogrammtidae). Aust. J. Entomol. 37: 174-179.

Chang S.C., Hu N.T., Hsin C.Y. \& Sun C.N. 2001: Characterization of differences between two Trichogramma wasps by molecular markers. Biol. Control 21: 75-78.

De LeÓN J.H. \& Jones W.A. 2005: Genetic differentiation among geographic populations of Gonatocerus ashmeadi, the predominant egg parasitoid of the glassy-winged sharpshooter, Homalodisca coagulata. J. Insect Sci. 5: 1-9.

Erlandson M., Braun L., Baldwin J., Soroka M., Ashfaq M. \& Hegedus D. 2003: Molecular markers for Peristenus spp. (Hymenoptera: Braconidae) parasitoids associated with Lygus spp. (Hemiptera: Miridae). Can. Entomol. 135: 71-83.

Greenstone M.H. \& Edwards M.J. 1998: DNA hybridization probe for endoparasitism by Microplitis croceipes (Hymenoptera: Braconidae). Ann. Entomol. Soc. Am. 91: 415-421.

Hoy M.A., Jeyaprakash A., Morakote R., Lo P.C. \& NGuyen R. 2000: Genomic analyses of two populations of Ageniaspis citricola (Hymenoptera: Encyrtidae) suggest that a cryptic species may exist. Biol. Control 17: 1-10.

Landais I., Chavigny P., Castagnone C., Pizzol J., Abad P. \& Vanlerberghe-Masutti F. 2000: Characterization of a highly conserved satellite DNA from the parasitoid wasp Trichogramma brassicae. Gene 255: 65-73.

Landry B.S., Dextraze L. \& Boivin G. 1993: Random amplified polymorphic DNA markers for DNA fingerprinting and genetic variability assessment of minute parasitic wasp species (Hymenoptera: Mymaridae and Trichogrammatidae) used in biological control programs of phytophagous insects. Genome 36: 580-587.

Laurent V., Wajnberg E., Mangin B., Schiex T., Gaspin C. \& Vanlerberghe-Masutti F. 1998: A composite genetic map of the parasitoid wasp Trichogramma brassicae based on RAPD markers. Genetics 150: 275-282.

Li Z.X., Zheng L. \& Shen Z.R. 2004: Using internally transcribed spacer 2 sequences to re-examine the taxonomic status of several cryptic Trichogramma species (Hymenoptera: Trichogrammatidae). Eur. J. Entomol. 101: 347-358.

LiN N.Q. 1994: Systematic Studies of Chinese Trichogrammatidae (Hymenoptera: Chalcidoidea). Fujian Science and Technology Publishing House, Fuzhou, Fujian, 362 pp. [in Chinese].

Loxdale H. \& MacDonald C. 2004: Tracking parasitoids at the farmland field scale using microsatellites markers. In Werner D. (ed.): Biological Resources \& Migration. Proceedings of the International Conference and OECD Workshop. Springer, Berlin, pp. 107-126. 
MacDonald C. \& Loxdale H.D. 2004: Molecular markers to study population structure and dynamics in beneficial insects (predators and parasitoids). Int. J. Pest Manag. 50: 215-224.

Nagarkatti S. \& Nagaraja H. 1971: Redescription of some known species of Trichogramma (Hymenoptera: Trichogrammatidae), showing the importance of the male genitalia as a diagnostic character. Bull. Entomol. Res. 61: 13-21.

Orrego C. \& Silva F.A. 1993: Genetic variation in the parasitoid wasp Trichogramma (Hymenoptera: Trichogrammatidae) revealed by DNA amplification of a section of the nuclear ribosomal repeat. Fla Entomol. 76: 519-524.

Pinto J.D., Stouthamer R., Platner G.R. \& Oatman E.R. 1991: Variation in reproductive compatibility in Trichogramma and its taxonomic significance. (Hymenoptera: Trichogrammatidae). Ann. Entomol. Soc. Am. 84: 37-46.

Pinto J.D., Kazmer D.J., Platner G.R. \& Sassaman C.A. 1992: Taxonomy of the Trichogramma minutum complex (Hymenoptera: Trichogrammatidae): allozymic variation and its relationship to reproductive and geographic data. Ann. Entomol. Soc. Am. 85: 413-422.

Pinto J.D., Stouthamer R. \& Platner G.R. 1997: A new cryptic species of Trichogramma (Hymenoptera: Trichogrammatidae) from the Mojave Desert of California as determined by morphological, reproductive and molecular data. Proc. Entomol. Soc. Wash. 99: 238-247.

Pinto J.D., Koopmanschap A.B., Platner G.R. \& Stouthamer R. 2002: The North American Trichogramma (Hymenoptera: Trichogrammatidae) parasitizing certain Tortricidae (Lepidoptera) on apple and pear, with ITS2 DNA characterizations and description of a new species. Biol. Control 23: 134-142.

Pinto J.D., Platner G.R. \& Stouthamer R. 2003: The systematics of the Trichogramma minutum Complex (Hymenoptera: Trichogrammatidae), a group of important North American biological control agents: The evidence from reproductive compatibility and allozymes. Biol. Control 27: 167-180.

Pintureau B. 1993: Enzymatic analysis of the genus Trichogramma (Hymenoptera: Trichogrammatidae) in Europe. Entomophaga 38: 411-431.

Prinsloo G., Chen Y., Giles K.L. \& Greenstone M.H. 2002: Release and recovery in South Africa of the exotic aphid parasitoid Aphelinus hordei Kurdjumov (Hymenoptera: Aphelinidae) verified by the polymerase chain reaction. BioControl 47: 127-136.
Ratcliffe S.T., Robertson H.M., Jones C.J., Bollero G.A. \& Weinzierl R.A. 2002: Assessment of house fly and stable fly pupae (Diptera: Muscidae) by Pteromalid (Hymenoptera: Pteromalidae) parasitoids using polymerase chain reaction. $J$. Med. Entomol. 39: 52-60.

Sappal N.P., Jeng R.S., Hubbes M. \& Liu F. 1995: Restriction fragment length polymorphisms in polymerase chain reaction amplified ribosomal DNAs of three Trichogramma (Hymenoptera: Trichogrammatidae) species. Genome 38: 419-25.

Silva I.S., Honda J., Van Kan F.M., Hu J., Neto L., Pintureau B. \& Stouthamer R. 1999: Molecular differentiation of five Trichogramma species occurring in Portugal. Biol. Control 16: $177-184$.

Stouthamer R., Luck R.F., Pinto J.D., Platner G.R. \& StePHENS B. 1996: Non-reciprocal cross-incompatibility in Trichogramma deion. Entomol. Exp. Appl. 80: 481-489.

Stouthamer R., Hu J., Van Kan F.M. \& Platner G.R. 1999: The utility of internally transcribed spacer 2 DNA sequences of the nuclear ribosomal gene for distinguishing sibling species of Trichogramma. BioControl 43: 421-440.

Stouthamer R., Jochemsen P., Platner G.R. \& Pinto J.D. 2000: Crossing incompatibility between Trichogramma minutum and T. platneri and its implications for their application in biological control. Environ. Entomol. 29: 827-837.

Thomson, L.J., Rundle B.J., Carew M. \& Hoffmann A.A. 2003: Identification and characterization of Trichogramma species from south-eastern Australia using the internal transcribed spacer (ITS-2) region of the ribosomal gene complex. Entomol. Exp. Appl. 106: 235-240.

Tilmon K.J., Danforth B.N., Day W.H. \& Hoffmann M.P. 2000: Determining parasitoid species composition in a host population: a molecular approach. Ann. Entomol. Soc. Am. 93: 640-647.

Van Kan F.M., Silva I.S., Schilthuizen M., Pinto J.D. \& Stouthamer R. 1996: Use of DNA-based methods for the identification of minute wasps of the genus Trichogramma. Proc. Exp. Appl. Entomol. 7: 233-237.

Zhu Y.C. \& Williams L.III. 2002: Detecting the egg parasitoid Anaphes iole (Hymenoptera: Mymaridae) in tarnished plant bug (Heteroptera: Miridae) eggs by using a molecular approach. Ann. Entomol. Soc. Am. 95: 359-365.

Received December 21, 2006; revised and accepted February 26, 2007 